УДК 528.94(477.75)

\title{
ПРИМЕНЕНИЕ СПУТНИКОВЫХ СНИМКОВ SЕNTINEL-2 ДЛЯ АНАЛИЗА ЗЕМЕЛЬ ИСПОЛЬЗУЕМЫХ В СЕЛЬСКОМ ХОЗЯЙСТВЕ (НА ПРИМЕРЕ РАЗДОЛЬНЕНСКОГО РАЙОНА РЕСПУБЛИКИ КРЫМ)
}

Табунщик В.А. ${ }^{1}$, Петлюкова Е.А. ${ }^{1}$, Хитрин М.O. ${ }^{2}$

${ }^{1}$ ФГАОУ ВО «Крымский федеральный университет имени В.И. Вернадского», 2. Симферополь, Российская Федераиия, e-mail: tabunshchyk@ya.ru, petlukova@mail.ru ${ }^{2}$ ФГАОУ ВО «Южно-Уральский государственный университет (начиональный исследовательский университет)», НОЦ «Геоинформачионные системы», г. Челябинск, Российская Федерация, e-mail: hitrymax@gmail.com

В статье рассматривается понятие о вегетационных индексах (Ratio Vegetation Index, Infrared Percentage Vegetation Index, Difference Vegetation Index, Soil adjusted vegetation index, Normalized Difference Vegetation Index) и приводится теория и методика использования космических снимков Sentinel для расчета значений Normalized Difference Vegetation Index (NDVI). Для территории Раздольненского района Республики Крым изучены значения Normalized Difference Vegetation Index (NDVI) за период с 16 февраля 2017 г. по 17 октября 2017 г., на основании открытых космических снимков Sentinel (Sentinel-2A и Sentinel-2B). Анализируются минимальные, максимальные и средние значения NDVI за рассматриваемы период, а также распределение территории Раздольненского района Республики Крым по различным диапазонам дискретной шкалы NDVI за рассматриваемый период (в процентах от общей площади района). На основании значений NDVI рассматривается использование земель Раздольненского района в сельскохозяйственной деятельности.

Ключевые слова: Sentinel; NDVI; Крым; Крымский полуостров; Раздольненский район; вегетационный индекс.

\section{Введение}

Со времени воссоединения Республики Крым и России в 2014 году происходит постепенная интеграция Республики Крым в пространство России. Одной из важнейших проблем которая должна быть решена - это проблема неиспользуемых и малоиспользуемых в сельском хозяйстве земель, так как территория Республики Крым обладает уникальными природными ресурсами (климатическими, земельными и др.), которые должны быть использованы в полной мере.

\section{Материалы и методы}

Цель исследования - обосновать возможность применения космических снимков Sentinel-2 и вегетационного индекса NDVI для анализа земель, используемых в сельском хозяйстве (на примере Раздольненского района Республики Крым).

Основными методами исследования в работе выступают: литературноаналитический, исторический, картографический, геоинформационный, сравнительногеографический.

Для апробации методики исследования на территории Республики Крым была выбрана территория Раздольненского района (рис. 1), согласно Закона Республики Крым «Об административно-территориальном устройстве Республики Крым» от 28 мая 2014 года (Закон Республики ..., 2018).

Раздольненский район расположен в степи на северо-западе Республики Крым на побережье Каркинитского залива. Граничит на севере - с Красноперекопским районом, на юге - с Черноморским районом, на востоке - с Первомайским районом, а с северо-запада омывается водами Черного моря. 


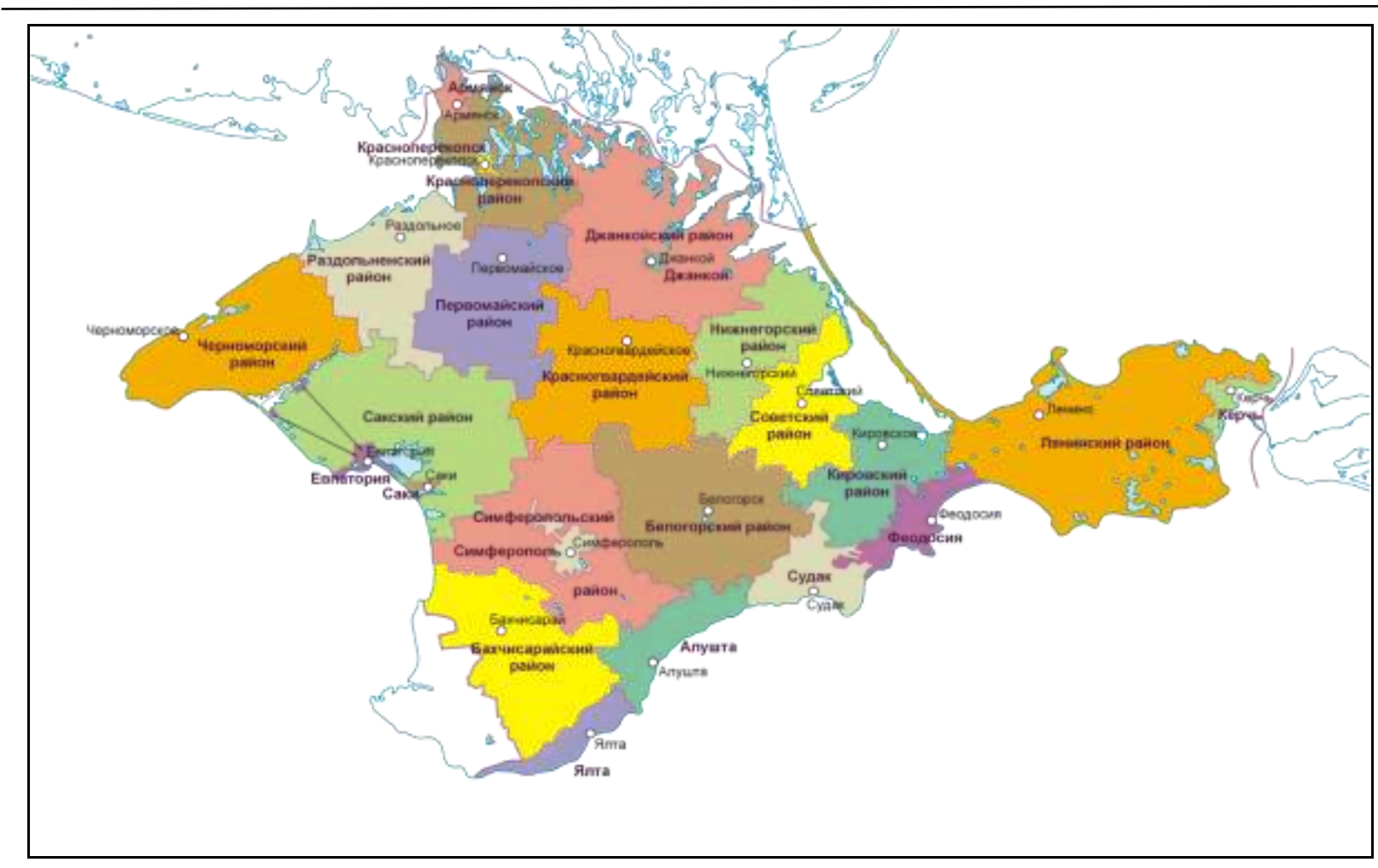

Рис. 1. Географическое положение Раздольненского района Республики Крым, по (Административно-территориальное..., 2018)

Площадь Раздольненского района составляет 1231 кв. км (4.7\% от общей площади территории Республики Крым). Административным центром района является Раздольное, расстояние от которого до столицы Республики Крым г. Симферополя составляет 135 км. В состав муниципального образования входят 41 населенный пункт: два поселка городского типа (Раздольное и Новоселовское) и 39 сел (Раздольненский район, 2018). Район имеет сложную ландшафтную структуру, представленную гидроморфным и плакорным ландшафтным уровнями. В структуре природопользования Раздольненского района Республики Крым преобладают сельскохозяйственные земли - 91.5\%, в том числе пашня $76.6 \%$ от общей площади района (рис. 2). Естественными ландшафтами занято только $3.3 \%$ площади района. Остальная территория - 5.2\% - занята селитебными и промышленными объектами (Калинчук, Петлюкова, 2017).

Вегетационный индекс - «это показатель, рассчитываемый в результате операций с разными спектральными диапазонами (каналами) ДДЗ, и имеющий отношение к параметрам растительности в данном пикселе снимка» (Вегетационные индексы, 2018).

Существуют различные вегетационные индексы, однако для расчета многих из них, используют соотношение красного (RED) и инфракрасного (NIR) каналов спутниковых снимков. Некоторые из них представлены в таблице 1.

Однако, наиболее распространенным и часто используемым (Hunt, et al., 2013; Черепанов, Дружинина, 2009; Черепанова, Девятков, 2008; Черепанов, 2011; Пахучий, Пахучая, 2014; Шевела, Погорелов, 2010; Погорелов, Кузнецов, Стебловский, 2011; Братков и др., 2016; Терехин, 2015; Савин, Танов, Харзинов, 2015; Кузьмин, Хитрин, Бегашев, 2015; Гунин и др., 2004) является нормализованный разностный вегетационный индекс (Normalized Difference Vegetation Index, NDVI). 


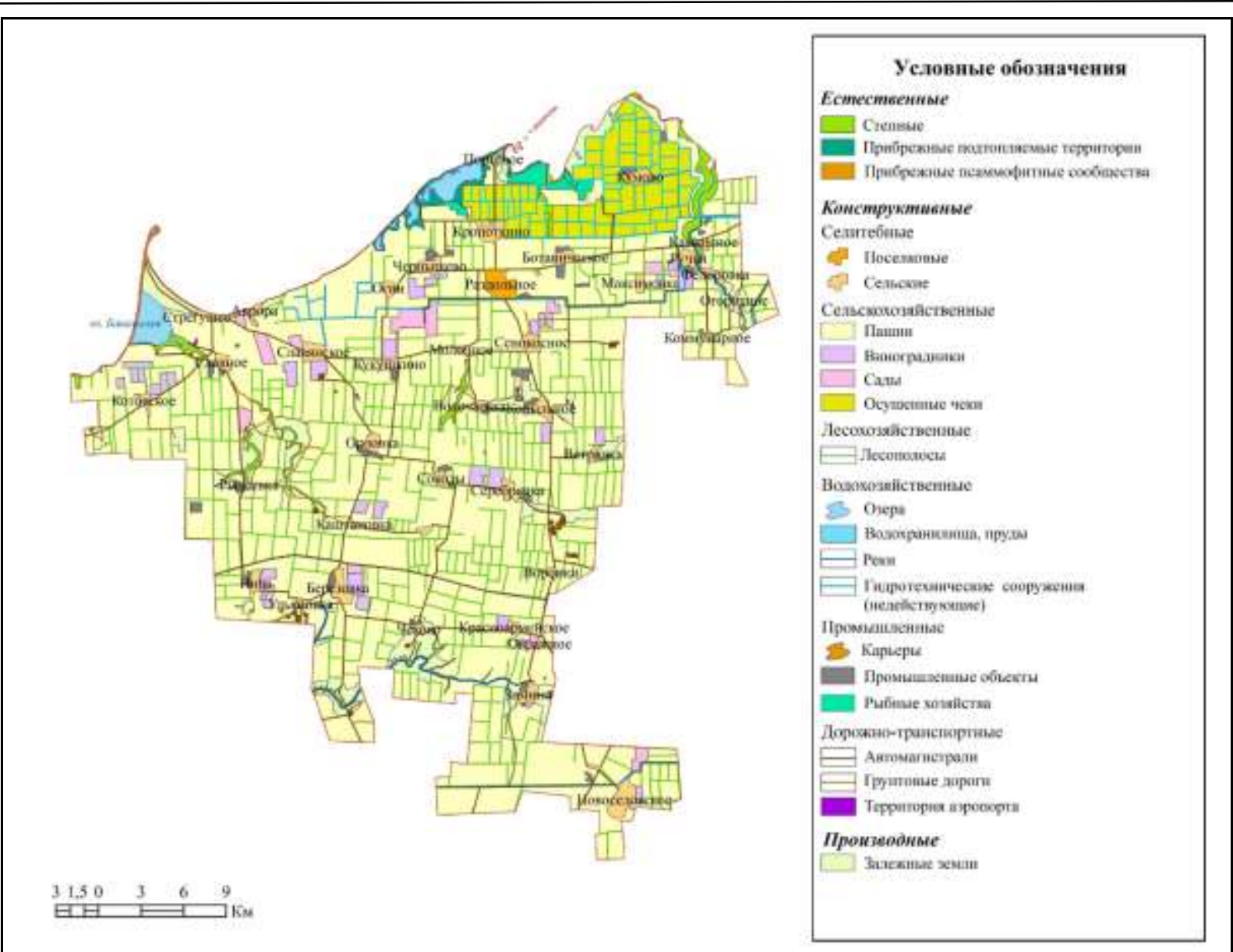

Рис. 2. Хозяйственная подсистема современных ландшафтов Раздольненского района Республики Крым, по (Калинчук И.В., Петлюкова Е.А., 2017)

Некоторые вегетационные индексы

\begin{tabular}{|c|c|c|}
\hline Название на английском языке & Название на русском языке & Формула расчета \\
\hline $\begin{array}{l}\text { RVI - Ratio Vegetation Index (Jordan, } \\
\text { 1969) }\end{array}$ & $\begin{array}{l}\text { Относительный } \\
\text { вегетационный индекс }\end{array}$ & $\mathrm{RVI}=\mathrm{NIR} / \mathrm{RED}$ \\
\hline $\begin{array}{l}\text { IPVI - Infrared Percentage Vegetation Index } \\
\text { (Crippen, 1990) }\end{array}$ & $\begin{array}{l}\text { Инфракрасный } \\
\text { вегетационный индекс }\end{array}$ & $\mathrm{IPVI}=\mathrm{NIR} /(\mathrm{NIR}+\mathrm{RED})$ \\
\hline $\begin{array}{l}\text { DVI - Difference Vegetation Index } \\
\text { (Richardson, Everitt, 1992) }\end{array}$ & $\begin{array}{l}\text { Разностный вегетационный } \\
\text { индекс }\end{array}$ & $\mathrm{DVI}=\mathrm{NIR}-\mathrm{RED}$ \\
\hline $\begin{array}{l}\text { SAVI - Soil adjusted vegetation index } \\
\text { (Huete, 1988) }\end{array}$ & $\begin{array}{l}\text { Вегетационный индекс } \mathrm{c} \\
\text { коррекцией по почве }\end{array}$ & $\begin{array}{l}\mathrm{SAVI}=(1+0.5)(\mathrm{NIR}-\mathrm{RED}) /( \\
\mathrm{NIR}+\mathrm{RED}+0.5)\end{array}$ \\
\hline
\end{tabular}

NDVI (Normalized Difference Vegetation Index, нормализованный разностный вегетационный индекс) - простой количественный показатель количества фотосинтетически активной биомассы. Один из самых распространенных и используемых индексов для решения задач, использующих количественные оценки растительного покрова. Может принимать значения от -1 до +1 (Kriegler, et al., 1969; Rouse, et al., 1973; NDVI - теория..., 2018). Так, по (NDVI - теория...), для густой растительности значения NDVI составляют 0,7 ; разреженной растительности - 0,5 ; открытой почвы 0,025 ; воды - $(-0,25)$; искусственных материалов - $(-0,5)$.

Вычисляется по следующей формуле:

$$
\mathrm{NDVI}=\frac{\mathrm{NIR}-\mathrm{RED}}{\mathrm{NIR}+\mathrm{RED}}
$$


где NIR - отражение в ближней инфракрасной области спектра, RED отражение в красной области спектра.

По формуле (1), значение каждого пикселя NDVI равно разнице интенсивностей отраженного света в красном и инфракрасном диапазоне, деленной на сумму их интенсивностей.

Основой исследования послужили снимки Sentinel-2. По классификации, приведенной в работе (Книжников, Кравцова, Тутубалина, 2004) они относятся к снимкам высокого разрешения.

Sentinel-2 - семейство спутников дистанционного зондирования Земли Европейского космического агентства, созданное в рамках проекта глобального мониторинга окружающей среды и безопасности «Коперник» (англ. Copernicus). На данный момент представлено двумя спутниками - Sentinel-2A и Sentinel-2B. Запуск спутника Sentinel-2A состоялся 23 июня 2015 года, а спутника Sentinel-2B - 7 марта 2017 года. О перспективности использования данных Sentinel говорилось еще в 2011 (Дворкин, 2011). Таким образом территорию Раздольненского района Республики Крым покрывают как спутник Sentinel-2А так и спутник Sentinel-2B.

На спутниках Sentinel-2 установлена мультиспектральная камера, которая позволяет осуществлять съемку в 13 спектральных каналах, предоставляя на выходе снимки различного пространственного расширения - 4 канала в 10-метровом разрешении, 6 каналов в 20-метровом разрешении и 3 канала в 60-метровом разрешении (табл. 2).

Таблица 2.

Характеристика космических снимков Sentinel-2

\begin{tabular}{|l|c|}
\hline Каналы Sentinel-2 & Разрешение, м \\
\hline Band 1 - Coastalaerosol & 60 \\
\hline Band 2 - Blue & 10 \\
\hline Band 3 - Green & 10 \\
\hline Band 4 - Red & 10 \\
\hline Band 5 - VegetationRedEdge & 20 \\
\hline Band 6 - VegetationRedEdge & 20 \\
\hline Band 7 - VegetationRedEdge & 20 \\
\hline Band 8 - NIR & 10 \\
\hline Band 8A - Narrow NIR & 20 \\
\hline Band 9 - Watervapour & 60 \\
\hline Band 10 - SWIR - Cirrus & 60 \\
\hline Band 11 - SWIR & 20 \\
\hline Band 12 - SWIR & 20 \\
\hline
\end{tabular}

10-метровое разрешение каналов, используемых для расчета вегетационных индексов, дает большее преимущество в использовании космических снимков открытого доступа, по сравнению со спутниковыми снимками Landsat, у которых красный (Red) и ближний инфракрасный (NIR) каналы имеют 30-метровое разрешение.

\section{Результаты и обсуждение}

На территорию Раздольненского района Республики Крым были выбраны космические снимки Sentinel-2 (Sentinel-2A и Sentinel-2B) покрывающие территорию района за период с февраля по октябрь 2017 года (табл. 3) и имеющие минимальные (менее 5\%) показатели облачности. В дальнейшем была произведена обрезка космических снимков по границе территории Раздольненского района Республики Крым (рис. 3) 


\section{Снимки Sentinel-2 покрывающие территорию Раздольненского района}

Таблица 3. Республики Крым

\begin{tabular}{|c|lll|}
\hline Спутник & \multicolumn{3}{|c|}{ Дата } \\
\hline \multirow{3}{*}{ Sentinel-2A } & 16 февраля 2017 г. & 17 мая 2017 г. & 28 августа 2017 г. \\
& 28 марта 2017 г. & 16 июня 2017 г. & 4 октября 2017 г. \\
& 27 апреля 2017 г. & 8 августа 2017 г. & 17 октября 2017 г. \\
\hline \multirow{3}{*}{ Sentinel-2В } & 01 июля 2017 г. & 12 сентября 2017 г. & \\
& 14 июля 2017 г. & 19 сентября 2017 г. & \\
& 31 июля 2017 г. & & \\
\hline
\end{tabular}

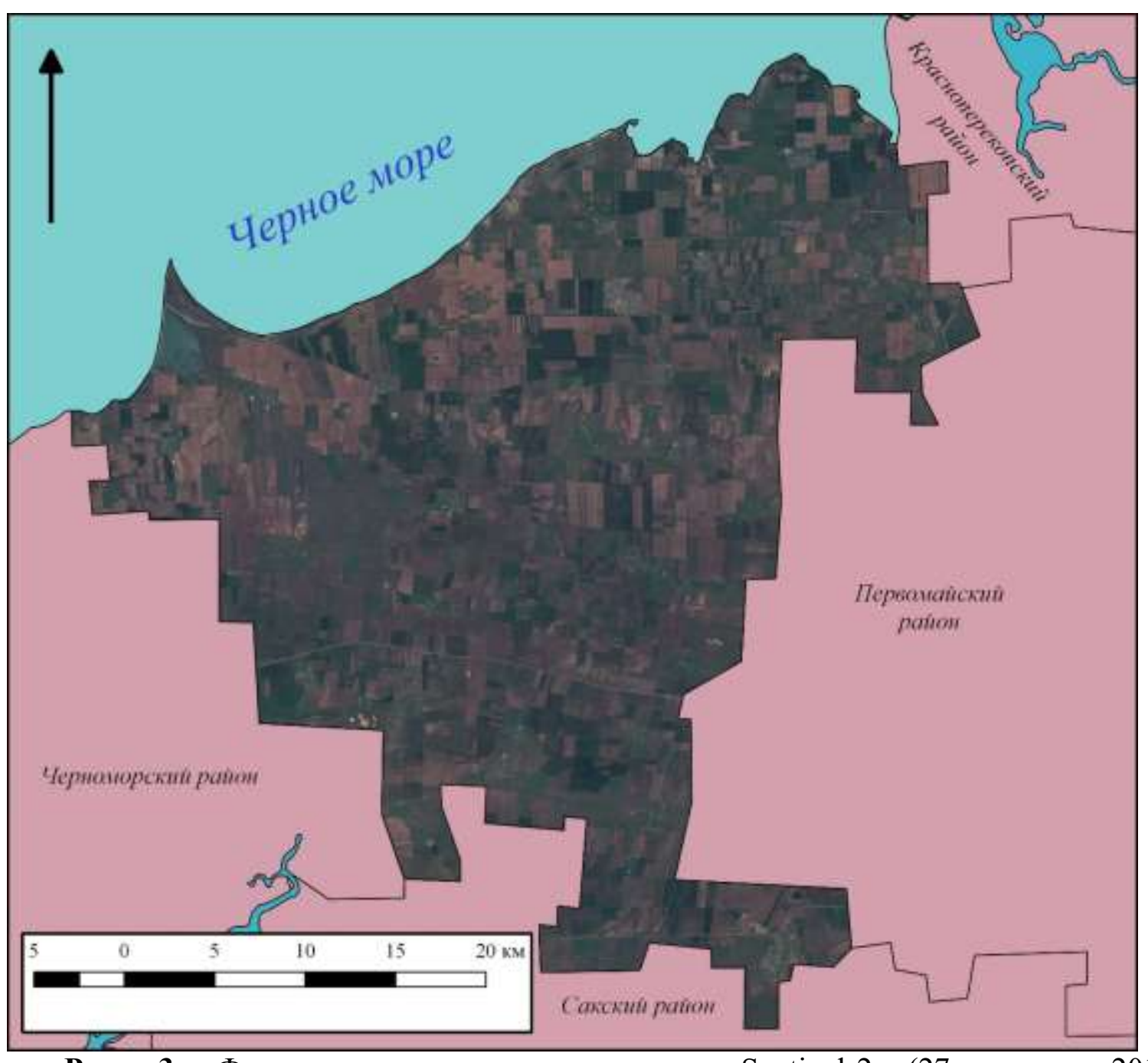

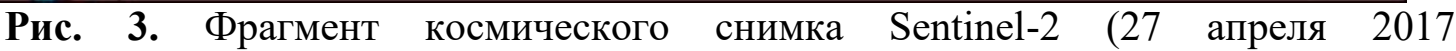
года) покрывающий территорию Раздольненского района Республики Крым

B программном комплексе QGIS были загружены многоканальные космические снимки Sentinel-2 (табл. 3) и с помощью «Калькуратора растров», по формуле (1), было рассчитано значение NDVI для перечисленных выше дат (рис. 4). Визуальный анализ рисунка 4 показывает, что максимальные значения NDVI характерны для периода с апреля по июнь 2017 года. Дополнительно, для каждой рассматриваемой даты была произведена выборка (табл. 4), по результатам которой были найдены максимальное и минимальное значения NDVI, а также среднее значение и среднее значение с учетом только положительного диапазона значений NDVI (на территории Раздольненского района Республики Крым присутствуют как крупные водные объекты (например, озеро Бакальское), так и ряд мелких - которые придают NDVI отрицательные значения). 


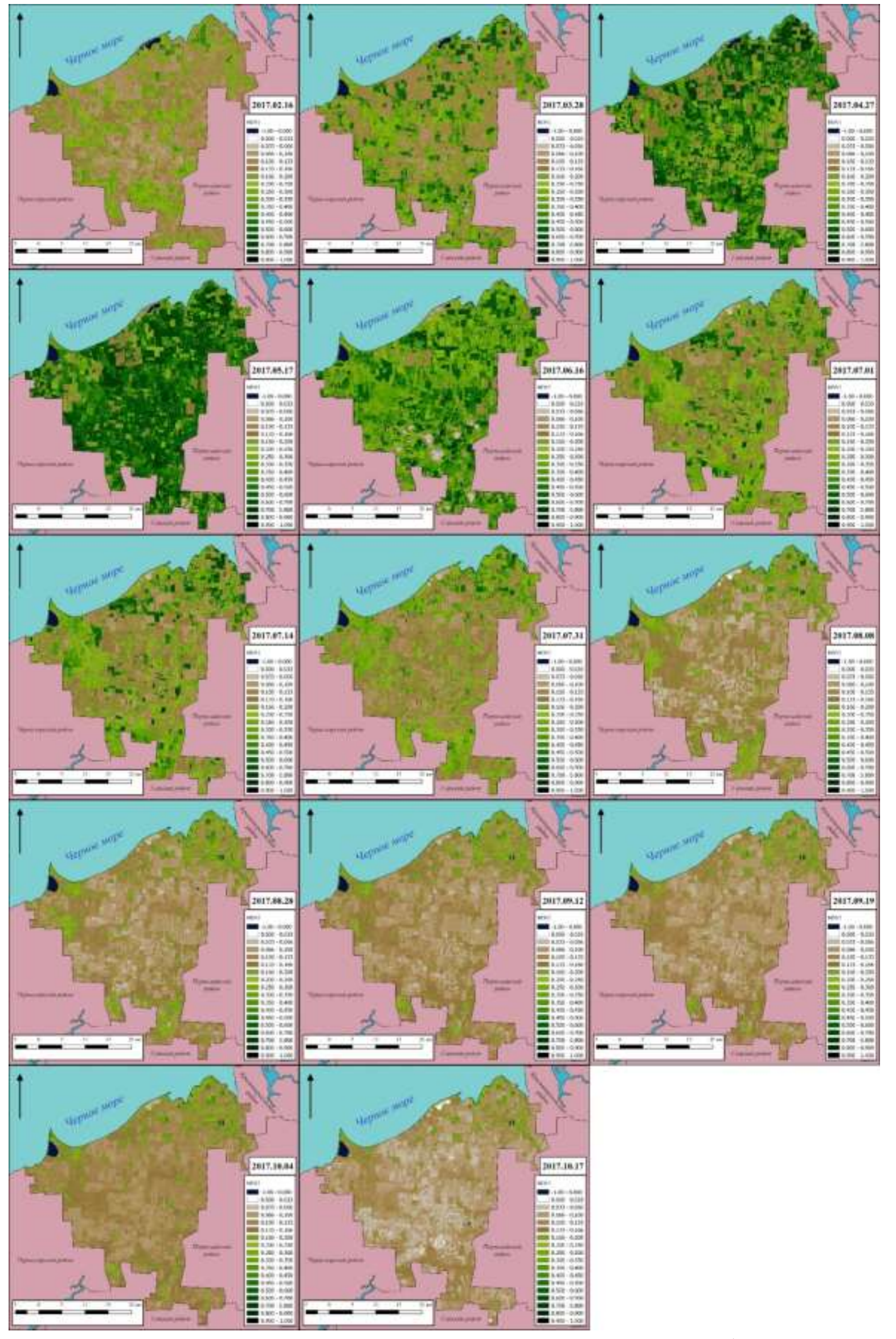

Рис. 4. Значение NDVI для Раздольненского района Республики Крым за рассматриваемый период 
Таблица 4.

Минимальное, максимальное, среднее и среднее (с учетом только положительного диапазона значений NDVI) значения NDVI за рассматриваемый период

\begin{tabular}{|l|c|c|c|c|}
\hline \multirow{2}{*}{ Дата } & \multicolumn{3}{|c|}{ NDVI } & $\begin{array}{c}\text { Среднее (с учетом только } \\
\text { положительного диапазона } \\
\text { значений NDVI) }\end{array}$ \\
\cline { 2 - 5 } & Минимум & Максимум & Среднеe & 0,17 \\
\hline 16 февраля 2017 г. & $-0,59$ & 0,65 & 0,16 & 0,25 \\
\hline 28 марта 2017 г. & $-0,62$ & 0,81 & 0,25 & 0,41 \\
\hline 27 апреля 2017 г. & $-0,66$ & 0,87 & 0,40 & 0,49 \\
\hline 17 мая 2017 г. & $-0,52$ & 0,83 & 0,49 & 0,37 \\
\hline 16 июня 2017 г. & $-0,58$ & 0,84 & 0,36 & 0,24 \\
\hline 01 июля 2017 г. & $-0,41$ & 0,76 & 0,24 & 0,24 \\
\hline 14 июля 2017 г. & $-0,46$ & 0,85 & 0,23 & 0,19 \\
\hline 31 июля 2017 г. & $-0,62$ & 0,99 & 0,19 & 0,14 \\
\hline 8 августа 2017 г. & $-0,47$ & 0,78 & 0,14 & 0,13 \\
\hline 28 августа 2017 г. & $-0,49$ & 0,78 & 0,13 & 0,12 \\
\hline 12 сентября 2017 г. & $-0,44$ & 0,76 & 0,12 & 0,14 \\
\hline 19 сентября 2017 г. & $-0,48$ & 0,78 & 0,12 & 0,10 \\
\hline 4 октября 2017 г. & $-0,65$ & 0,83 & 0,13 & \\
\hline 17 октября 2017 г. & $-0,58$ & 0,82 & 0,10 & \\
\hline
\end{tabular}

Максимальные значения NDVI колеблются в диапазоне от 0.65 (16 февраля 2017 года) до 0.99 (31 июля 2017 года). Минимальные значения NDVI колеблются в диапазоне от -0.66 (27 апреля 2017 года) до -0.41 (01 июля 2017 года). Следует отметить что максимальные и минимальные значения NDVI не отражают ситуацию в целом, а лишь фиксируют максимальное и минимальное значение информации, которая присуща в пикселе (например, значение NDVI равное 0.99), для которого и производится расчет. Более объективную ситуацию показывает распределение среднего значения NDVI по рассматриваемым датам. Средние значения NDVI колеблются в диапазоне от 0.10 (17 октября 2017 года) до 0.49 (17 мая 2017 года). Одновременно с этим максимальные средние значения приходятся на 27 апреля 2017 года (0.41), 17 мая 2017 года (0.49) и 16 июня 2017 года (0.37). Это совпадает и с визуальной оценкой, представленной выше.

Показатели среднего значения NDVI и среднего значения NDVI с учетом только положительного диапазона значений практически не отличаются, что свидетельствует о незначительной площади территории, на которую приходятся эти значения (табл. 5).

В таблице 5 представлено распределение территории Раздольненского района Республики Крым по различным диапазонам дискретной шкалы NDVI за рассматриваемый период в процентах от общей площади района. Здесь следует оговорится про снимки, полученные за 16 июня 2017 года, т.к. частично на них присутствует облачность, но ее процент не так велик что бы помешало нам использовать снимок в наших исследованиях.

Наибольшие значения NDVI приходятся на снимок от 17 мая 2017 года, когда на более чем 50\% площади района, значения NDVI достигают более 0.5 . В дальнейшем, на большей территории Раздольненского района Республики Крым значения NDVI приходятся на диапазон от 0.0 до 0.2 , что в целом повторяет средние значения, представленные в таблице 4. 


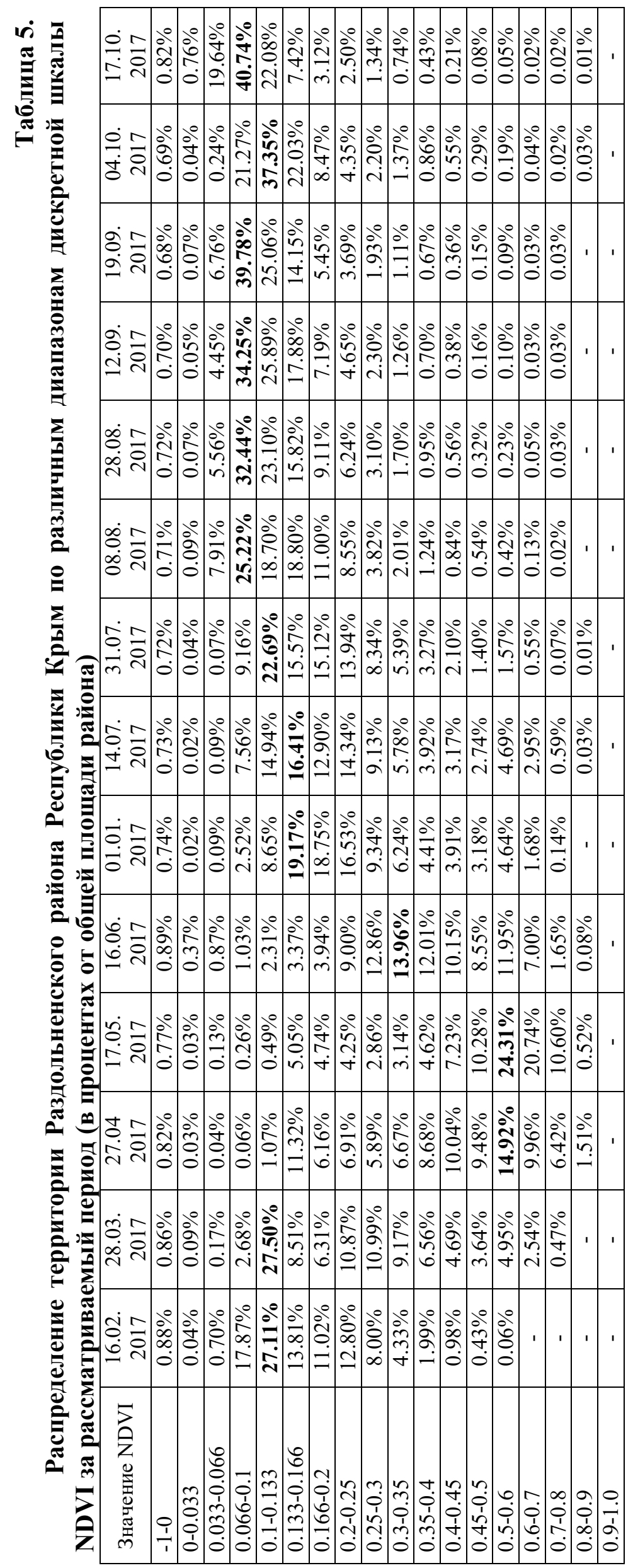


Рассмотренная выше характеристика может нарушается от места к месту в зависимости от использования каждого конкретного земельного участка и может служить для целей выявления неиспользуемых сельскохозяйственных земель. Поскольку наибольшие значения NDVI для Раздольненского района Республики Крым в целом достигаются на карте, построенной по космическим снимкам от 17 мая 2017 года, то территории полей, которые предположительно не используются в сельском хозяйстве и имеют минимальные значения NDVI легко определяются. Для дополнительного анализа используется анализ карт значения NDVI за другие даты. Изначально на карте значения NDVI, построенной по спутниковым данным от 17 мая 2017 года, выделяются территории которые предположительно не имеют растительности, что соответствует низким значениям NDVI. Так как на некоторых территориях пик значения индекса NDVI приходится на другие месяцы (что связано с особенностями развития различных сельскохозяйственных культур), то производится корректировка и исключение выделенных участков, там, где в феврале, марте, июне, июле и августе 2017 года наблюдается высокие значения NDVI. В сентябре и октябре 2017 года на выбранных участках показатели NDVI визуально не отличаются от показателей за август, поэтому дополнительные построения не проводились. В результате были выбраны территории которые в течении рассматриваемого периода предположительно не используются в сельском хозяйстве (рис. 5). Их площадь составила 20.3 кв. км.

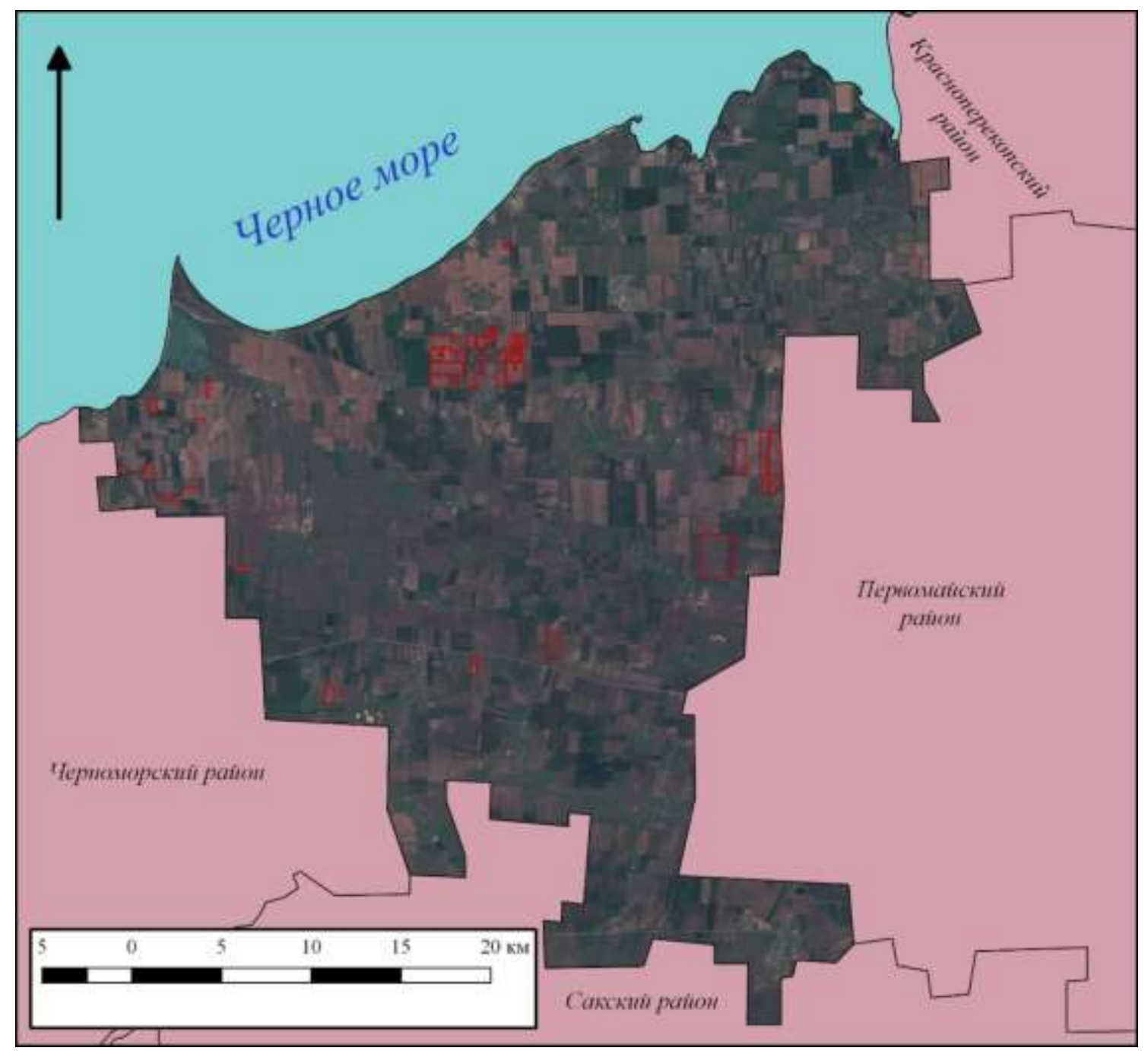

Рис. 5. Выделение неиспользуемых земель на территории Раздольненского района Республики Крым 
На следующем этапе выяснялось производилась ли сельскохозяйственная обработка выделенных земель - вспашка в течении рассматриваемого периода. В качестве исходного показателя были выбраны показатели значения NDVI за 16 февраля 2017 года, когда земли еще не были вспаханы. В дальнейшем показатели значений NDVI за другие месяцы сравнивались с февральскими показателями. При этом выяснялась динамика значений индекса NDVI для выделенных земель. Для этого использовалось меню растр и инструмент «Калькулятор растров» в программном комплексе QGIS. Если происходило увеличение значений NDVI по сравнению с контрольной датой, то считалось что земли используются (вспашка, зарастание и пр.), если же уменьшение или незначительное колебание значений около нуля - не используется. На основании этого были дополнительно построены карты, отражающие изменение значений индекса NDVI на землях предположительно неиспользуемых в сельском хозяйстве (рис. 6).

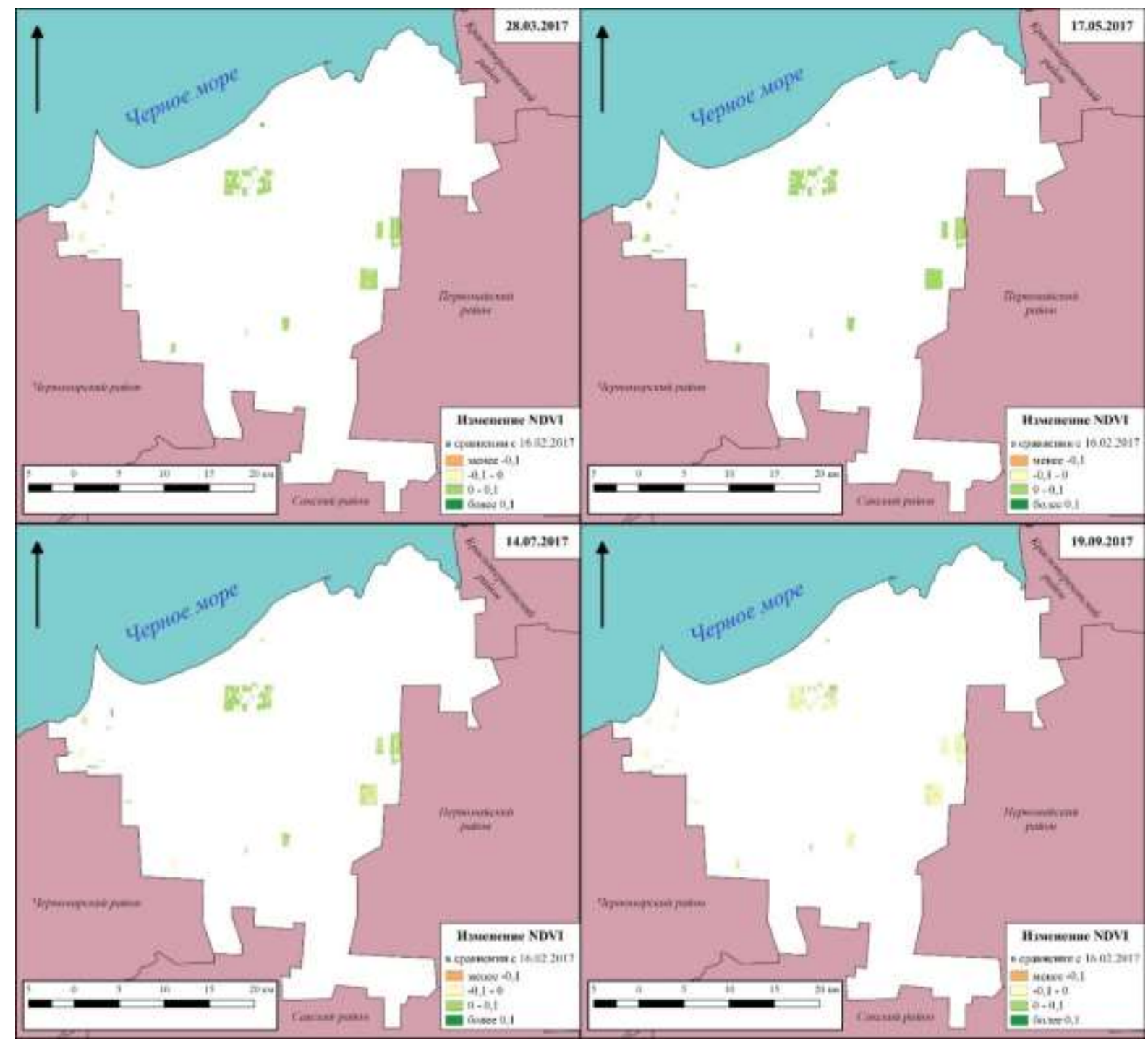

Рис. 6. Динамика значений NDVI на на землях предположительно неиспользуемых в сельском хозяйстве в сравнении со значением на 16 февраля 2017 года

Как видно из рисунка 6, на землях предположительно неиспользуемых в сельском хозяйстве в течении весны и лета 2017 наблюдается прирост значений индекса NDVI в диапазоне от 0 до 0.1. В сентябре наблюдаются отрицательная 
динамика значений индекса NDVI. Рассмотрим это более детально на примере участков, расположенных к северу от села Кукушкино Раздольненского района Республики Крым (рис. 7). Для каждого участка был проведен детальный анализ изменения значений NDVI в течении рассматриваемого периода (таблица 6). Так на участках 1 и 2 - средние значения NDVI не превышают 0.15 , на 3 участке -0.27 . На этих участках отсутствуют ярко выраженные признаки вегетации, в отличие от 4 участка, где среднее значение NDVI достигает 0.76. По сравнению с расчетами значений NDVI от 16 февраля 2017 года, наблюдается прирост в большинство последующих месяцев (рис. 8).

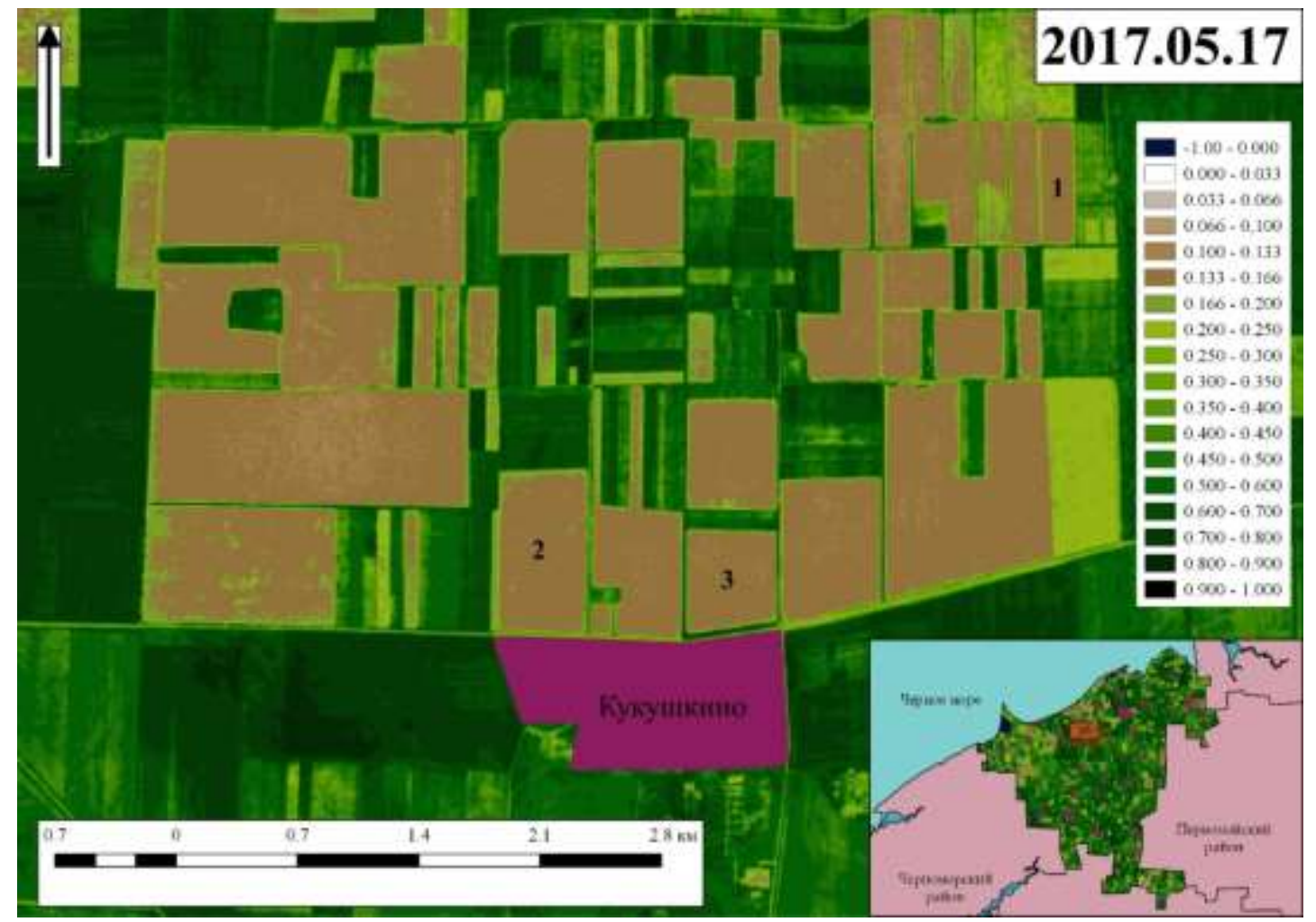

Рис. 7. Рассматриваемые участки к северу от села Кукушкино

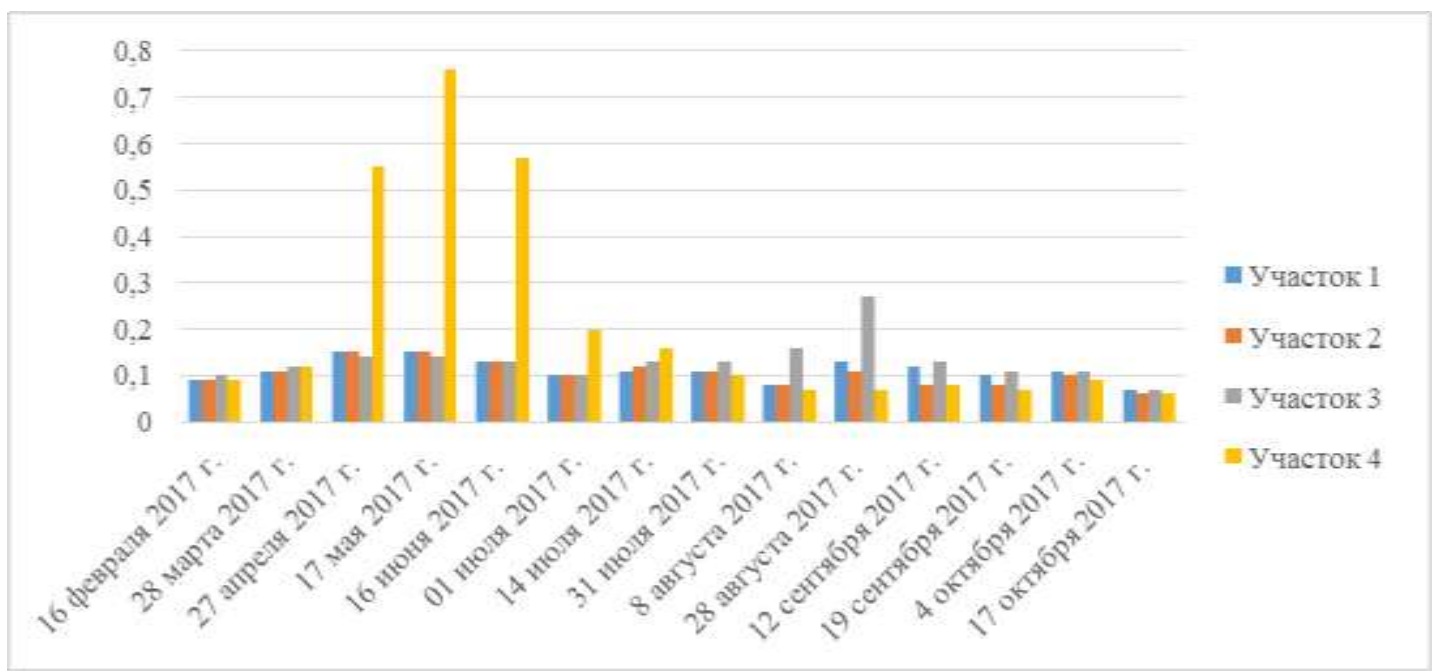

Рис. 8. Средние значения NDVI на рассматриваемых участках за период с 16 февраля 2017 г. по 17 октября 2017 г. 


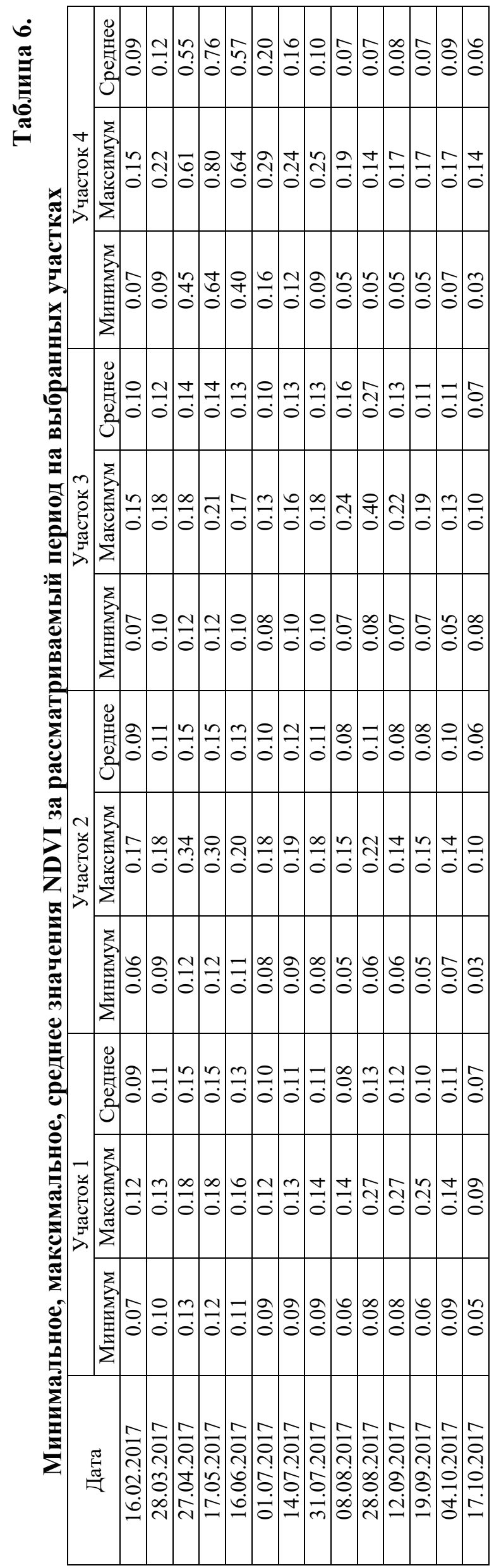


Таким образом мы можем считать, что выбранные участки так же используются, и территория Раздольненского района Республики Крым активнейшим образом вовлечена в сельскохозяйственную деятельность.

\section{Выводы}

1. Максимальные значения NDVI на территории Раздольненского района Республики Крым достигаются в период с апреля по июнь 2017 года.

2. Максимальные значения NDVI колеблются в диапазоне от 0.65 (16 февраля 2017 года) до 0.99 (31 июля 2017 года). Минимальные значения NDVI колеблются в диапазоне от -0.66 (27 апреля 2017 года) до -0.41 (01 июля 2017 года). Средние значения NDVI колеблются в диапазоне от 0.10 (17 октября 2017 года) до 0.49 (17 мая 2017 года). Максимальные средние значения приходятся на 27 апреля 2017 года (0.41), 17 мая 2017 года (0.49) и 16 июня 2017 года (0.37).

3. Значения NDVI, рассчитанные по данным космических снимков Sentinel-2 за период с 16 февраля по 17 октября 2017 года, показывают, что на территории Раздольненского района Республики Крым все земли, доступные для ведения сельскохозяйственной деятельности, используются, так как наблюдается рост значений NDVI в весенне-летне-осенний период.

Настоящая работа выполнена при поддержке Программы развития Федерального государственного автономного образовательного учреждения высшего образования «Крымский федеральныий университет имени В.И. Вернадского»на 20152024 годы в рамках реализачии академической мобильности по проекту ФГАОУ ВО «КФУ им. В.И. Вернадского» "Сеть академической мобильности «ГИС-Ландмафт Технологии и методики формирования геопорталов современных ландмафтов регионов» в Федеральном государственном автономном образовательном учреждении выстего образования «Южно-Уральский государственный университет (национальный исследовательский университет)» (г. Челябинск) в 2017 году.

\section{Список литературы}

1. Административно-территориальное деление Республики Крым [Электронный pecypc]. - Режим доступа: https://ru.wikipedia.org/wiki/Административнотерриториальное_деление_Республики_Крым (дата обращения 01.03.2018)

2. Братков В.В., Кравченко И.В., Туаев Г.А., Атаев 3.В., Абдулжсалимов А.А. Применение вегетационных индексов для картографирования ландшафтов Большого Кавказа / // Известия Дагестанского государственного педагогического университета. Естественные и точные науки. - 2016. - Т. 10. - № 4. - С. 97-111.

3. Вегетационные индексы [Электронный ресурс]. - Режим доступа: http:/gislab.info/qa/vi.html (дата обращения 01.03.2018)

4. Гунин П.Д., Золотокрылин А.Н., Виноградова В.В., Бажа С.Н. Динамика состояния растительного покрова южной Монголии по данным NDVI // Аридные экосистемы. - 2004. - Том 10. - № 24-25. - С. 29-34.

5. Дворкин Б.А. Европейская программа GMES и перспективная группировка спутников Д33 Sentinel // Геоматика. - 2011. - № 3. - С. 14-26.

6. Закон Республики Крым «Об административно-территориальном устройстве Республики Крым» от 28 мая 2014 года [Электронный ресурс]. - Режим доступа: http://crimea.gov.ru/textdoc/ru/6/act/18z.pdf (дата обращения 01.03.2018)

7. Калинчук И.В., Петлюкова Е.А. Современные ландшафты Раздольненского района Республики Крым // Охрана природы и региональное развитие: гармония и 
конфликты (к Году экологии в России): материалы международной научнопрактической конференции и школы-семинара молодых ученых-степеведов «Геоэкологические проблемы степных регионов», проведённых в рамках XXI сессии Объединенного научного совета по фундаментальным географическим проблемам при Международной ассоциации академий наук (МАAН) и Научного совета РАН по фундаментальным географическим проблемам, п. Партизанский Бузулукского района Оренбургской области, 01-05 октября 2017 года. Т. I. [Текст]: сб. науч. трудов. - Оренбург: Институт степи УрО РАН, 2017. - С. 300-304.

8. Книжников Ю.Ф., Кравцуова В.И., Тутубалина О.В. Аэрокосмические методы географических исследований. - М.: Издательский центр «Академия», 2004. - 336 с.

9. Кузьмин А.Ю., Хитрин М.О., Бегашев М.Ф. Тематическая классификация по типам сельскохозяйственных культур // Актуальные вопросы геоинформатики. Челябинск: Издательский центр ЮУрГУ, 2015. - С. 26-32.

10. Пахучий В.В., Пахучая Л.М. Опыт использования вегетационных индексов при комплексных исследованиях на объектах гидролесомелиорации // Вестник Поволжского государственного технологического университета. Сер.: Лес. Экология. Природопользование. - 2014. - № 1 (21). - С. 33-41.

11. Погорелов А.В., Кузнецов К.В., Стебловский А.С. Оценка состояния сельскохозяйственных посевов по вегетационному индексу (пространственный аспект) // Геоинформационное обеспечение пространственного развития Пермского края. - 2011. - Выпуск 4. - С. 4-7.

12. Раздольненский район [Электронный ресурс]. - Режим доступа: http://razdolnoe.rk.gov.ru/rus/about.htm (дата обращения 01.03.2018)

13. Савин Ю.И., Танов Э.Р., Харзинов С. Использование вегетационного индекса NDVI для оценки качества почв пашни (на примере Баксанского района КабардиноБалкарии) // Бюллетень Почвенного института им. В.В. Докучаева. - 2015. - Вып. 77. - C. 51-65.

14. Терехин Э.А. Оценка сезонных значений вегетационного индекса (NDVI) для детектирования и анализа состояния посевов сельскохозяйственных культур // Исследование Земли из космоса. - 2015. - № 1. - С. 23-31.

15. Черепанов А.С. Вегетационные индексы // Геоматика. - 2011. - № 2. - С. 98-102

16. Черепанов А.C., Дружинина E.Г. Спектральные свойства растительности и вегетационные индексы // Геоматика. - 2009. - № 3. - С. 28-32.

17. Черепанова Е.С., Девятков С.Ю. Использование индекса растительности (NDVI) как метода контроля за состоянием лесных ресурсов Пермского края // Геоинформационное обеспечение пространственного развития Пермского края. Пермь: Пермский государственный университет, 2008. - С. 155-166.

18. Шевела С.Ю., Погорелов А.В. Вегетационный индекс NDVI как индикатор ландшафтов Краснодарского края // Географические исследования Краснодарского края. - 2010. - Выпуск 5. - С. 262-268.

19. Crippen R.E. Calculating the Vegetation Index Faster // Remote Sensing of Environment. - 1990. - Vol. 34. - pp. 71-73.

20. Huete A.R. A soil-adjusted vegetation index (SAVI) // Remote Sensing of Environment. 1988. - Volume 25. - Issue 3. - pp. 295-309.

21. Hunt E., Doraiswamy P., McMurtrey J., Daughtry C., Perry E., Akhmedov B. A visible band index for remote sensing leaf Chlorophyll content at the Canopy Scale // International Journal of Applied Earth Observation and Geoinformation. - 2013. Volume 21. - pp. 103-112.

22. Jordan C.F. Derivation of leaf area index from quality of light on the forest floor // Ecology. - 1969. - Vol. 50. - pp. 663-666. 
23. Kriegler F.J., Malila W.A., Nalepka R.F., Richardson W. Preprocessing transformations and their effects on multispectral recognition // Proceedings of the Sixth International Symposium on Remote Sensing of Environment. - Ann Arbor: University of Michigan, 1969. - pp. 97-131.

24. NDVI - теория и практика [Электронный ресурс]. - Режим доступа: http:/gislab.info/qa/ndvi.html (дата обращения 01.03.2018)

25. Richardson A.J., Everitt J.H. Using spectra vegetation indices to estimate rangeland productivity // Geocarto International. - 1992. -Vol. 1. - pp. 63-69.

26. Rouse J.W., Haas R.H., Schell J.A., Deering D.W. Monitoring vegetation systems in the great plains with ERTS // Third ERTS Symposium, NASA SP-351. - 1973. - Vol. 1. pp. 309-317.

\section{THE USE OF SATELLITE IMAGERY SENTINEL-2 FOR ANALYSIS OF LAND USED IN AGRICULTURE (FOR EXAMPLE RAZDOLNENSKY DISTRICT OF THE REPUBLIC OF CRIMEA) \\ Tabunshchyk V.A. ${ }^{1}$, Petlukova E.A. ${ }^{1}$, Hytrin M.O. ${ }^{2}$ \\ ${ }^{l}$ V.I. Vernadsky Crimean Federal University, Simferopol, Russian Federation, e-mail: tabunshchyk@ya.ru,petlukova@mail.ru \\ ${ }^{2}$ South Ural State University (national research university), Chelyabinsk, Russian Federation,e-mail: hitrymax@gmail.com}

In the article the concept of vegetation indices (Ratio Vegetation Index, Infrared Percentage Vegetation Index, Difference Vegetation Index, Soil adjusted vegetation index, Normalized Difference Vegetation Index) are given and the theory and methodology of using satellite images Sentinel to calculate the values of Normalized Difference Vegetation Index (NDVI) are provided. For the territory of Razdolnensky district of the Republic of Crimea are analyzed the value of the Normalized Difference Vegetation Index (NDVI) for the period from February 16, 2017 on October 17, 2017, based on open space images of Sentinel (Sentinel-2A and Sentinel-2B). The minimum, maximum and average NDVI values for the period under review, as well as the distribution of the territory of the Razdolnensky district of the Republic of Crimea over different ranges of the discrete NDVI scale for the period under review (as a percentage of the total area of the area) are analyzed. On the basis of NDVI values use of lands of Razdolnensky district in agricultural activity is considered.

Key words: Sentinel; NDVI; Crimea; Crimean Peninsula; Razdolnensky district; vegetation index.

Поступила в редакичию 05.03.2018 г. 